Supplement of Biogeosciences Discuss., 12, 933-980, 2015

http://www.biogeosciences-discuss.net/12/933/2015/

doi:10.5194/bgd-12-933-2015-supplement

(C) Author(s) 2015. CC Attribution 3.0 License.

(c) (i)

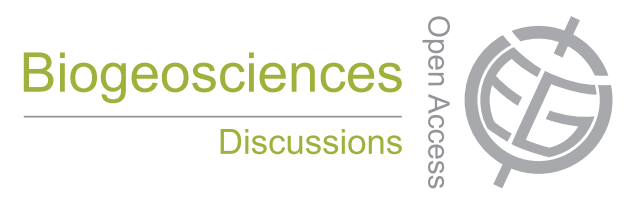

Supplement of

\title{
Carbon budget estimation of a subarctic catchment using a dynamic ecosystem model at high spatial resolution
}

\section{J. Tang et al.}

Correspondence to: J. Tang (lu.gistangjing@gmail.com) 


\section{Section S1: Model Descriptions}

Here, we provide an overview of the hydrological processes and C cycling in LPJG-WHyMeTFM and more detailed descriptions of LPJ-GUESS and LPJ-GUESS WHyMe can be found in the cited references below.

LPJ-GUESS is a climate-driven, process-oriented model with dynamic vegetation as well as soil biogeochemistry (Smith et al., 2001). Vegetation dynamics are explicitly represented and include stochastic plant establishment, mortality and disturbance, operating in a number of independent, replicate patches in each grid cell. Each patch in the same grid cell is driven by the same climate forcing. Vertical stand structure and dynamics in the model are represented in the replicate patches, which contain potential plant function types (PFTs) of different age classes (cohorts) competing for light and water. PFTs are grouped based on their physiological, phenological and morphological characteristics. Bioclimatic limits determine which PFTs can establish in a given climate (Wramneby et al., 2008). The parameterization of non-peatland PFTs in this study is based on the previous studies conducted in the arctic region (Wolf et al., 2008; Hickler et al., 2012; Miller and Smith, 2012; Zhang et al., 2013), while peatland PFTs are described in Wania et al. (2009a) and Zhang et al. (2013). All PFTs simulated in the Stordalen catchment is listed in Table S1. To account for peatland hydrology, methane emission and permafrost soils at high latitudes, LPJ-GUESS has been developed to include the same implementations of these processes first introduced to LPJ-DGVM (Wania et al., 2009a, b, 2010). We refer to this model version as LPJ-GUESS WHyMe - see the following paragraphs as well as Miller and Smith (2012), McGuire et al. (2012) and Zhang et al. (2013) for further details.

Table S1. Plant functional Types (PFTs) and typical species simulated in Stordalen catchment.

\begin{tabular}{ll}
\hline PFT name & Typical Species \\
\hline pmoss & Sphagnum spp. \\
(peatland moss) & \\
WetGRS & Carex spp. \\
(Flood-tolerant graminoid) & \\
IBS & Betula pubescens \\
(Shade-intolerant broadleaved summergreen tree) & \\
\hline
\end{tabular}




\begin{tabular}{ll}
\hline HSE & Juniperus communis \\
(Tall evergreen shrub) & \\
LSE & Vaccinium vitis-idaea \\
(Low evergreen shrub) & \\
HSS & Salix spp., Betula nana \\
(Tall summergreen shrub) & \\
C3G & Gramineae \\
(Cold C3 grass) & \\
BNE & Picea abies \\
(Boreal shade-tolerant needle-leaved evergreen tree) & \\
BINE & Pinus sylvestris \\
(Boreal shade-intolerant needle-leaved evergreen tree) & \\
\hline
\end{tabular}

\section{Distributed Hydrology}

In LPJG-WHyMe-TFM, the non-peatland hydrology scheme is mainly based on Gerten et al. (2004) and considers the vertical water movement between atmosphere, vegetation and soil. The modelled water processes include vegetation interception, transpiration, infiltration, percolation, soil evaporation from bare soil and runoff. The vegetation-intercepted water amount is a function of PFT type, leaf area index and precipitation, while transpired water is closely related to photosynthesis, PFT root distribution and soil water content (Sitch et al., 2003). Soil evaporation occurs on bare ground and is a function of soil water content. Before evapotranspiration is calculated, surface and subsurface runoff can be generated if water reaching the soil column is in excess of the soil water holding capacity. However, the generated runoff is assumed to leave the model domain without considering routing to downslope areas in LPJ-GUESS and LPJ-GUESS WHyMe. Recently, however, an algorithm developed by Tang et al. (2014b) has overcome this limitation by incorporating topographical effects on water redistribution within a catchment boundary. Topographic indices (drainage area, flow direction and slope) estimated from a digital elevation model (DEM) are used to quantify the topographical variations and coupled into LPJGUESS.

The first implementation of topographical indices in LPJ-GUESS (Tang et al., 2014b) was based on a single flow (SF) algorithm, which directs water to the steepest downslope grid cell. However, the substantial differences in water partitioning and routing between the single and multiple flow algorithms are not negligible (Wilson et al., 2007; Pilesjö and Hasan, 2014). Therefore, the hydrological and ecological consequences of different flow algorithms were further quantified and investigated within the framework of LPJ-GUESS WHyMe. In Tang et al. 
(2014a), an advanced multiple flow algorithm TFM was chosen (Pilesjö and Hasan, 2014), due to the improved treatment of flow continuity and flow estimation over flat surfaces. The coupled model, here referred to as LPJG-WHyMe-TFM was found to agree more closely with hydrological measurements in the same domain used in this study and, moreover, greatly enhanced the model's simulation of carbon (C) fluxes for the study area's low-lying peatland (Tang et al., 2014a). Therefore, in this study, the model coupled with the TFM algorithm (LPJGWHyMe-TFM) is implemented to study the full C budget.

\section{Peatland hydrology}

In LPJG-WHyMe-TFM, the peatland hydrology is based on Wania et al. (2009a). In contrast to the non-peatland soil layering, an acrotelm-catotelm soil structure was applied, assuming a permanently inundated body of peat under the top $0.3 \mathrm{~m}$, down to $2 \mathrm{~m}$ depth, while the top $0.3 \mathrm{~m}$ has a fluctuating water table. In addition, standing water (up to $10 \mathrm{~cm}$ ) is allowed for the peat soils, to allow for water held by the peatland vegetation (Wania et al., 2009a). Fluctuations of the water table position $(W T P)$ are based on soil water volume together with soil porosity. The detailed calculations of WTP can be found in Wania et al. (2009a) and Tang et al. (2014a). Both peatland and non-peatland grid cells can receive water from upslope areas. The lateral water movement within the catchment directly influences soil water content, and thereby vegetation growth and soil processes.

\section{Methane Biogeochemistry and Transport}

In LPJ-GUESS WHyMe, an extra potential C pool for methanogens $\left(\mathrm{C}_{\mathrm{CH} 4}\right)$ has been added for peatland cells and it mainly includes root exudates and easily-decomposed materials (Wania et al., 2010). The root exudates are also included for the upland cells. The $\mathrm{C}_{\mathrm{CH} 4}$ is proportionally distributed in the soil layer following a fixed root biomass distribution. The $\mathrm{C}$ allocated to $\mathrm{C}_{\mathrm{CH} 4}$ consists of (see dashed red lines in Fig. 1): (1) the decomposed root exudates materials which are a fixed fraction of NPP; (2) a fraction of decomposed litter; (3) a fraction of quickly decomposing soil organic matter (fSOM); and (4) a fraction of slowly decomposing soil C pool (sSOM). The overall decomposition rate in the model is strongly influenced by soil temperature and moisture. The soil temperature response in both mineral and peatland soils is exponential and based on the modified Arrhenius equation (Lloyd and Taylor, 1994). the moisture response 
is a function of WTP, with a linear transformation from aerobic to anaerobic decomposition as WTP increases from its minimum value of $-300 \mathrm{~mm}$ to $100 \mathrm{~mm}$ above ground (see Eq. 5 in (Tang et al., 2014a)). For peatland, the majority of $\mathrm{C}_{\mathrm{CH} 4}$ is located in the acrotelm layer and the oxidation and production of $\mathrm{CH}_{4}$ together decide the net emission of $\mathrm{CH}_{4}$. In the model, oxygen can enter into soil by diffusion or plant-transport. Oxidized methane with oxygen is turned into $\mathrm{CO}_{2}$, and the remaining $\mathrm{CH}_{4}$ can be released back to the atmosphere by plant-transport, diffusion and ebullition (see the lines with a solid arrow in Fig. 1). The emission rate of $\mathrm{CH}_{4}$ in the model depends on the degree of anoxia as well as on soil temperature and additionally, the planttransported $\mathrm{CH}_{4}$ depends on the presence or absence of aerenchyma tissue in vascular plants. Ebullition is determined by maximum solubility of $\mathrm{CH}_{4}$ in water (Wania et al., 2010). 


\section{Section S2: Flux comparisons between simulations with different $\mathrm{CO}_{2}$ driving}

Two simulations with different $\mathrm{CO}_{2}$ concentration driving are compared in Fig. S1, one assuming a constant $\mathrm{CO}_{2}$ concentration since 1960 (the dashed lines in Fig. S1) and the other with $\mathrm{CO}_{2}$ concentrations increasing to 639 ppm by 2080 (Fig. S1).
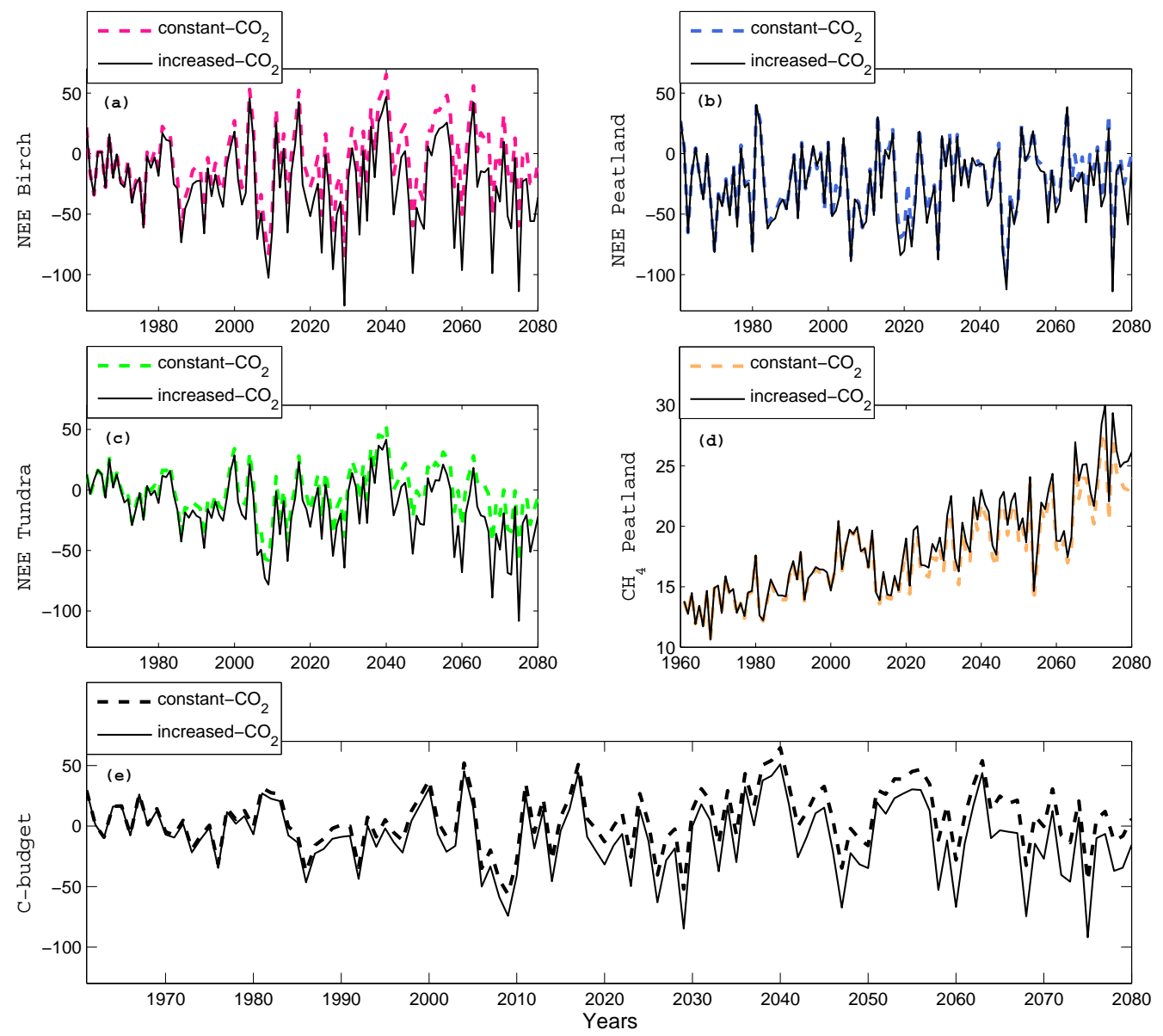

Figure S1. Carbon flux comparison between the simulation with constant $\mathrm{CO}_{2}$ inputs since 1960 and the simulation with increased $\mathrm{CO}_{2}$ concentration forcing from 1961-2080 (the majority of the results are given in Figure 7). 


\section{Reference}

Gerten, D., Schaphoff, S., Haberlandt, U., Lucht, W., and Sitch, S.: Terrestrial vegetation and water balance--hydrological evaluation of a dynamic global vegetation model, Journal of Hydrology, 286, 249-270, doi:10.1016/j.jhydrol.2003.09.029, 2004.

Hickler, T., Vohland, K., Feehan, J., Miller, P. A., Smith, B., Costa, L., Giesecke, T., Fronzek, S., Carter, T. R., Cramer, W., Kühn, I., and Sykes, M. T.: Projecting the future distribution of European potential natural vegetation zones with a generalized, tree species-based dynamic vegetation model, Global Ecology and Biogeography, 21, 50-63, doi:10.1111/j.14668238.2010.00613.x, 2012.

Lloyd, J., and Taylor, J. A.: On the Temperature Dependence of Soil Respiration, Functional Ecology, 8, 315-323, doi:10.2307/2389824, 1994.

McGuire, A. D., Christensen, T. R., Hayes, D., Heroult, A., Euskirchen, E., Kimball, J. S., Koven, C., Lafleur, P., Miller, P. A., Oechel, W., Peylin, P., Williams, M., and Yi, Y.: An assessment of the carbon balance of Arctic tundra: comparisons among observations, process models, and atmospheric inversions, Biogeosciences, 9, 3185-3204, doi:10.5194/bg-9-31852012, 2012.

Miller, P. A., and Smith, B.: Modelling Tundra Vegetation Response to Recent Arctic Warming, AMBIO: A Journal of the Human Environment, 41, 281-291, doi:10.1007/s13280-012-0306-1, 2012.

Pilesjö, P., and Hasan, A.: A Triangular Form-based Multiple Flow Algorithm to Estimate Overland Flow Distribution and Accumulation on a Digital Elevation Model, Transactions in GIS, 18, 108-124, doi:10.1111/tgis.12015, 2014.

Sitch, S., Smith, B., Prentice, I. C., Arneth, A., Bondeau, A., Cramer, W., Kaplan, J. O., Levis, S., Lucht, W., Sykes, M. T., Thonicke, K., and Venevsky, S.: Evaluation of ecosystem dynamics, plant geography and terrestrial carbon cycling in the LPJ dynamic global vegetation model, Global Change Biology, 9, 161-185, doi:10.1046/j.1365-2486.2003.00569.x, 2003.

Smith, B., Prentice, I. C., and Sykes, M. T.: Representation of vegetation dynamics in the modelling of terrestrial ecosystems: comparing two contrasting approaches within European climate space, Global Ecology and Biogeography, 10, 621-637, doi:10.1046/j.1466822X.2001.t01-1-00256.x, 2001.

Tang, J., Miller, P. A., Crill, P. M., Olin, S., and Pilesjö, P.: Investigating the influence of two different flow routing algorithms on soil-water-vegetation interactions using the dynamic ecosystem model LPJ-GUESS, Ecohydrology, doi:10.1002/eco.1526, 2014a.

Tang, J., Pilesjö, P., Miller, P. A., Persson, A., Yang, Z., Hanna, E., and Callaghan, T. V.: Incorporating topographic indices into dynamic ecosystem modelling using LPJ-GUESS, Ecohydrology, 7, 1147-1162, doi:10.1002/eco.1446, $2014 \mathrm{~b}$.

Wania, R., Ross, I., and Prentice, I. C.: Integrating peatlands and permafrost into a dynamic global vegetation model; 1, Evaluation and sensitivity of physical land surface processes, Global Biogeochemical Cycles, 23, doi:10.1029/2008gb003412, 2009a.

Wania, R., Ross, I., and Prentice, I. C.: Integrating peatlands and permafrost into a dynamic global vegetation model; 2, Evaluation and sensitivity of vegetation and carbon cycle processes, Global Biogeochemical Cycles, 23, doi:10.1029/2008gb003413, 2009 b.

Wania, R., Ross, I., and Prentice, I. C.: Implementation and evaluation of a new methane model within a dynamic global vegetation model: LPJ-WHyMe v1.3.1, Geosci Model Dev, 3, 565-584, doi:DOI 10.5194/gmd-3-565-2010, 2010. 
Wilson, J. P., Lam, C. S., and Deng, Y.: Comparison of the performance of flow-routing algorithms used in GIS-based hydrologic analysis, Hydrological Processes, 21, 1026-1044, doi:10.1002/hyp.6277, 2007.

Wolf, A., Callaghan, T., and Larson, K.: Future changes in vegetation and ecosystem function of the Barents Region, Climatic Change, 87, 51-73, doi:10.1007/s10584-007-9342-4, 2008.

Wramneby, A., Smith, B., Zaehle, S., and Sykes, M. T.: Parameter uncertainties in the modelling of vegetation dynamics-Effects on tree community structure and ecosystem functioning in European forest biomes, Ecological Modelling, 216, 277-290, doi:10.1016/j.ecolmodel.2008.04.013, 2008.

Zhang, W., Miller, P. A., Smith, B., Wania, R., Koenigk, T., and Döscher, R.: Tundra shrubification and tree-line advance amplify arctic climate warming: results from an individualbased dynamic vegetation model, Environmental Research Letters, 8, 034023, 2013. 